\title{
SURVEY OF INTERNATIONAL LAW LITERATURE PUBLISHED IN 2002 RELEVANT TO ASIAN AFFAIRS
}

\author{
Bimal N. Patel ${ }^{*}$
}

\section{Areas of international law:}

1. Air and space

13. Information and communication

2. Arbitration

3. Arms control and disarmament

4. Conflict and disputes

5. Criminal law and terrorism

6. Decolonization and self-determination

7. Development

8. Diplomatic and consular relations

9. Economic relations and International Finance

10. Environment

11. General

12. Individuals, groups of persons human rights

14. Peace-keeping, peace-making and peace-building

15. Peaceful settlement of international disputes

16. Sea, rivers and water-resources

17. States and groups of states

18. Territory and jurisdiction

19. United Nations and other international/regional organisations and regional laws

20. War, peace and neutrality, armed conflict, international humanitarian law
ALQ
Arab Law Quarterly
ASL Air Space Law
AUILR The American University International Law Review
CJIL Chinese Journal of International Law
CLP China Law and Practice
CLYIB Comparative Law Yearbook of International Business
DJCIL Duke Journal of Comparative and International Law
EJIL European Journal of International Law
ETL European Transport Law
FILJ Fordham International Law Journal

\footnotetext{
* Bimal N. Patel, PhD (International Law) researcher at Nijmegen University, The Netherlands. Staff member, Organisation for the Prohibition of Chemical Weapons, The Hague, The Netherlands. The author would like to express sincere thanks to Ms Ingrid Kost and Mr Jeroen Vervliet, Peace Palace Library, for providing valuable support in the compilation of this survey.
}

Asian Yearbook of International Law, Volume 9 (B.S. Chimni et al., eds.)

(C) 2004 Koninklijke Brill NV. Printed in The Netherlands, pp. 429-461. 
GIELR Georgetown International Environmental Law Review

GLJ The Georgetown Law Journal

IBL International Business Lawyer

ICAB International Court of Arbitration Bulletin

ICLQ International Comparative Law Quarterly

ICLR The International Construction Law Review

JALC Journal of Air Law and Commerce

JCSL Journal of Conflict and Security Law

JIA Journal of International Arbitration

JWT Journal of World Trade

LJIL Leiden Journal of International Law

NLR Nepal Law Review

OCDIL Ocean Development and International Law

OCULR Oklahoma City University Law Review

TMLJ Tulane Maritime Law Journal

VJTL Vanderbilt Journal of Transnational Law

\section{AIR AND SPACE}

ABEYRATNE, RUWANTISSA, The carriage by air of invasive alien species: regulatory and legal issues, ASL (2) 196-208

ABEYRATNE, RUWANTISSA, Air carriers' rights in refusing to board potentially unruly passengers - some comparative issues at common law, 37 ETL (4) 401410

CHAN, YU-CHUN and WILLIAMS, GEORGE, Prospects for changing airline ownership rules, 67 JALC (2) 233-240

FERRAO, PETER, Developing a system of dispute settlement for commercial activities in outer space, 68 Arbitration (3) 250-252

FREEMAN, PAUL and LAM, RAYMOND, Current Chinese aviation policy in the light of economic globalisation, 27 ASL (1) $48-58$

HAVEL, BRIAN F., International instruments in air, space and telecommunications law: the need for a mandatory supranational dispute settlement mechanism In Arbitra- tion in air, space and telecommunications law, ed. by the International Bureau of the Permanent Court of Arbitration, 11-57 (2002)

HIMMA, KENNETH EINAR, Situating Dworkin: the logical space between legal positivism and natural law theory, 27 OCULR (1) 41-150

JING, MEN, The US/China Aviation Collision Incident at Hainan in April 2001: China's perspective, 51 Zeitschrift für Luft- und Weltraumrecht (4) 557-570

MANZIONE, LARA L., Multinational investment in the Space Station: an outer space model for international cooperation, 18 AUILR (2) 507-535

RUEDA, ANDRES, The Warsaw convention \& electronic ticketing, 67 JALC (2) 401464

SUH, DON, Situating liberalism in transnational legal space, 12 DJCIL (2) 605630

VAN DE WOUWER, Jean Louis, Space law faces new challenges, 37 ETL (1) 37-51 
VAN FENEMA, PETER, The UNIDROIT Space Protocol, the concept of 'launching state', space traffic management and the delimitation of outer space: the 41st session of the UNCOPUOS legal subcommittee, Vienna, 2-12 April 2002, 27 ASL (4-5) 266-279

ZULLO, KELLY M., The need to clarify the status of property rights in international space law, 90 GLJ (6) 2413-2444

\section{ARBITRATION}

AL-SABAH, S.J., FEREIG, S.M. and HOARE, D.J., Construction claims: results from major tribunal findings in Kuwait, 68 Arbitration (1) 11-16

ARNOTT, JAMES M., Presenting evidence and arguments in an international arbitration, 23a CLYIB, 189-206

Award rendered by ICSID Arbitral Tribunal in the Case of Mihaly International Corporation v. Democratic Socialist Republic of Sri Lanka (ICSID Case No. ARB/00/ 2), 17 ICSID Review (1) 140-165

BAGOT, MICHAEL $H$. and HENDERSON, DANA A., Not party, not bound? Not necessarily: binding third parties to maritime arbitration, 26 TMLJ (2) 413-461

BALFOUR, JOHN, Arbitration in aviation: the ultimate remedy? In Arbitration in air, space and telecommunications law, edited by the International Bureau of the Permanent Court of Arbitration, 81-94 (2002)

BARRINGTON, LOUISE, Law to be applied in international arbitration, 23a CLYIB, 77-87

BÖCKSTIEGEL, KARL-HEINZ, The application of the UNIDROIT Principles to contracts involving states or intergovern- mental organizations, The ICC ICAB, Special supplement, 51-55 (2002)

BONELL, MICHAEL JOACHIM, The UNIDROIT Principles as a means of interpreting and supplementing international uniform law, The ICC ICAB, Special supplement, 29-38 (2002)

BOLIVIN, RICHARD, International arbitration with states: an overview of the risks, 19 JIA (4) 285-299

CARBONNEAU, THOMAS E. [et al.] Practitioner's handbook on international arbitration, ed. by Frank-Bernd Weigand, München: Beck, 1315p.

CHANG, WANG SHENG, Combination of arbitration with conciliation and remittance of awards: with special reference to the Asia-Oceania region, 19 JIA (1) $51-65$

CHAN, ANDREW and WOODWARD, ALISON, Singapore as a place for arbitration: recent developments, $69 \mathrm{Ar}$ bitration (1) 10-23

CLAVER-CARONE, MAURICIO J., Posthandover recognition and enforcement of arbitral awards between mainland China and Hong Kong SAR: 1999 Agreement vs. New York Convention, 33 Law policy int. bus. (2) 369-403

CRAWFORD, JAMES and SINCLAIR, ANTHONY, The UNIDROIT Principles and their application to state contracts, The ICC ICAB, Special supplement, 5775 (2002)

CROWTER, HAROLD S. and TOBIN, ANTHONY G.V., Ensuring that arbitration remains a preferred option for intellectual dispute resolution: some practical considerations, 19 JIA (4) 301-312 
DALY, BROOKS W., Correction and interpretation of arbitral awards under the ICC rules of arbitration, 13 The ICC ICAB (1) 61-71

DAVIS, BENJAMIN G., SYNDER, FRANKLIN G., Elkins, Kay, Manzo, Peter B., Gaitenby, Alan, and Larson, David Allen, The first international competition for online dispute resolution: is this big, different and new?, 19 JIA (4) 379-392

DESSEMONTET, F., Use of the UNIDROIT Principles to interpret and supplement domestic law, The ICC ICAB, Special supplement, 39-50 (2002)

DHARMANANDA, KANAGA, The unconscious choice: reflections on determining the lex arbitri, 19 JIA (2) 151161

ELSING, SIEGFRIED H. and TOWNSEND, JOHN M., Bridging the common lawcivil law divide in arbitration, 18 Arbitr. int. (1) 59-65

FATHALLAH, RAED MOUNIR, Investment disputes between states and private parties: enhancing private access through international arbitration In Looking ahead: International Law in the 21st century, ed. in chief Diane Hiscox, ed. Johanne Levasseur, 72-94

FISCHER, ROBERT DONALD and HAYDOCK, ROGER S., Drafting an enforceable arbitration agreement, 23a CLYIB, 29-76

FONTAINE, MARCEL, The UNIDROIT Principles: an expression of current contract practice?, The ICC ICAB, Special supplement, 95-98 (2002)

FOYLE, ANDREW, Use of experts in international arbitration, 23a CLYIB, 119-142
FRAZIER, KURT L., Arbitration to resolve international insurance and surety claims, 23a CLYIB, 281-310

HA, BINH T.T., Arbitration as a means of resolving business-related disputes in Vietnam: the present situation and prospective development, 19 JIA (4) 337-348

HADDAD, HAMZEH, Jordan: Arbitration Law No. 31 of 2001, 17 ALQ (3) 287303

HASSAN, TARIQ, International arbitration in Pakistan, 19 JIA (6) 591-600

HINCHEY, JOHN W. and BAER, ELIZABETH T., Exchanges of documents and depositions in international arbitration, 23a CLYIB, 207-227

HOWELL, DAVID, DUTHIE, LEIGH and LIM, MARK, International arbitration in Singapore: opting out of the UNCITRAL Model Law, 19 JIA (1) 39-50

HULBERT, RICHARD W., The international commercial arbitration model and public International Law disputes, 8 ILSA Journal of International \& Comparative Law (2) $501-506$

HWANG, MICHAEL and MUTTATH, RAJESH C., The role of the courts in the course of arbitral proceedings: Singapore and other Asian perspectives, 68 Arbitration (3) 223-237

JENNINGS, ROBERT, The differences between conducting a case in the ICJ and in an ad hoc arbitration tribunal: an inside view In Liber amicorum Judge Shigeru Oda, ed. by Nisuke Ando, Edward McWhinney and Rudiger Wolfrum, 893-909

KAPLAN, NEIL, Arbitration in Asia: developments and crisis, 19 JIA (2) 163-170 
LALIVE, PIERRE, The UNIDROIT Principles as lex contractus, with or without an explicit or tacit choice of law: an arbitrator's perspective, The ICC ICAB, Special Supplement, 77-83

LESERVOIR, LAURE, Enforcing arbitration awards and important conventions, 23a CLYIB, 255-264

LOWENFELD, ANDREAS F., International litigation and arbitration, Second Edn, St. Paul, MN: West Group, 2002, 948p.

MALLOY, MICHAEL P., Current issues in international arbitration, 15 The Transnational Lawyer (1) 43-54

MARRIOTT, ARTHUR, India and international arbitration, 68 Arbitration (3) 262-268

MILLS, KAREN, Judicial attitudes to enforcement of arbitral awards and other judicial involvement in arbitration in Indonesia, 68 Arbitration (2) 106-119

MAYER, PIERRE, The role of the UNIDROIT Principles in ICC arbitration practice, The ICC ICAB, Special Supplement, 105-117 (2002)

NETTO, ANNE M., Time clauses under the Singapore Institute of Architects' form of contract, 19 ICLR (2) 229-241

PARTASIDES, CONSTANTINE, The fourth arbitrator? the role of secretaries to tribunals in international arbitration, 18 Arbitr. Int. (2) $147-163$

PLATTE, MARTIN, When should an arbitrator join case?, 18 Arbitr. Int. (1) 6781

RAESCHKE-KESSLER, HILMAR, Making arbitration more efficient: settlement initiatives by the arbitral tribunal, 30 IBL (4) $158-164$
RAESCHKE-KESSLER, HILMAR, The UNIDROIT Principles in contemporary contract practice, The ICC ICAB, Special supplement, 99-104 (2002)

RAMASWAMY, P., Enforcement of annulled awards: an Indian perspective, 19 JIA (5) 461-472

REDDY, VINAY AND NAGARAJ, V. Arbitrability: the Indian perspective, 19 JIA (2) $117-149$

RODNER, JAMES O., International and national arbitration: a fading distinction, 19 JIA (5) 491-496

RUTLEDGE, PETER BOWMAN, On the importance of institutions: Review of arbitral awards for legal errors, 19 JIA (2) $81-116$

SILVA-ROMERO, EDUARDO, ICC arbitration and state contracts, 13 The ICC ICAB (1) 34-60

TRAKMAN, LEON E., Confidentiality in International Commercial Arbitration, 18 Arbitr. int. (1) 1-18

VON SEGESSER, GEORG, Witness preparation in international commercial arbitration, 28 Bulletin, Association suisse de l'arbitrage (2) 222-228

WOODWARD, ALISON, Finality of international arbitral awards in Singapore: recent developments, 76 The Law institute Journal (7) 56-60

WOUTERS, NORA, Grounds for refusal to enforce foreign arbitration awards, 23a CLYIB, 265-271

XYRE, TAMARA, Ethical codes of conduct for arbitrators and disciplinary proceedings of the Chartered Institute of Arbitrators, 68 Arbitration (2) 90-105 
YESILIRMAK, ALI, The Turkish International Arbitration Law of 2001, 19 JIA (2) $171-177$

ZEKOS, GEORGIOS I., Arbitration as a dispute settlement mechanism under UNCLOS, the Hamburg Rules, and WTO, 19 JIA (5) 497-504

\section{ARMS CONTROL AND DISARMAMENT}

A disarmament agenda for the twenty-first century: UN-China Disarmament Conference, Beijing, China, 2-4 April 2002 New York, NY: United Nations Department for Disarmament Affairs, 195p.

ALFREDSON, LISA, Child soldiers, displacement and human security, 3 Disarmament Forum 17-27

ASADA, MASAHIKO, CTBT: legal questions arising from its non-entry-into-force, 7 JCSL (1) 85-122

DANDO, MALCOLM, Scientific and technological change and the future of the CWC: the problem of non-lethal weapons, Disarmament Forum (4) 33-44

DONOHUE, LAURA K. and KAYYEM, JULIETTE N., Federalism and the battle over counterterrorist law: state sovereignty, criminal law enforcement, and national security, 25 Studies in conflict and terrorism (1) 1-18

FEAKES, DANIEL, Evaluating the CWC verification system, Disarmament Forum (4) $11-21$

FLECK, DIETER, Developments of the law of arms control as a result of the IraqKuwait conflict, 13 EJIL (1) 105-119

GORKA, SEBESTYHN and SULLIVAN, RICHARD, Biological toxins: a bio- weapon threat in the 21 st century, 33 Security Dialogue (2) International Peace Research Institute, Oslo (PRIO) 141-156

GRAHAM, THOMAS, Disarmament sketches: three decades of arms control and International Law Jr, Seattle [etc.]: Institute for global and regional security studies, $362 \mathrm{p}$.

KELLE, ALEXANDER, The first CWC Review Conference: taking stock and paving the way ahead, Disarmament Forum (4) 3-9

KERVERS, ONNO, Strengthening compliance with the Biological Weapons Convention: the protocol negotiations, 7 JCSL(2) 275-292

LEE, THERESE, Malaysia and the Internal Security Act : the insecurity of human rights after September 11, Singapore Journal of legal studies, National University of Singapore, Issue July 6-72

LIOTTA, P. H., Boomerang effect: the convergence of national and human security In 33 Security dialogue (4) 473-488, International Peace Research Institute, Oslo (PRIO)

ROJAS ARAVENA, FRANCISCO, Human security: emerging concept of security in the twenty-first century, Disarmament Forum (2) 5-14

SIEVERT, RONALD J., Urgent message to Congress - nuclear triggers to Libya, missile guidance to China, air defense to Iraq, arms supplier to the world : has the time finally arrived to overhaul the U.S. export control regime? - the case for immediate reform of our outdated, ineffective, and self-defeating export control system, 37 Texas International Law Journal (1) 89-109 
THOMAS, NICHOLAS and TOW, WILLIAM T., The utility of human security: sovereignty and humanitarian intervention In 33 Security dialogue (2) 177192 International Peace Research Institute, Oslo (PRIO)

ZANDERS, JEAN PASCAL, The Chemical Weapons Convention and universality: a question of quality over quantity?, Disarmament Forum (4) 23-31

\section{CONFLICT AND DISPUTES}

COHEN, JEROME A., Dispute resolution in China: putting the house in order, 15 CLP (10) 36-38

EFFENDI, MARIA SAIFUDDIN, Conflict resolution in South Asia: applicable theories and approaches, Pakistan horizon, vol. 55, issue $3,41-57$

FREEDSON, JULIA, The impact of conflict on children: the role of small arms, 3 Disarmament Forum 37-44

HAMPSON, FEN OSLER, MALONE, DAVID M., Improving the UN's capacity for conflict prevention, 9 International Peacekeeping (1) 77-98

PRYLES, MICHAEL (ed.), Dispute resolution in Asia, Second edn, Kluwer Law International, 410p.

REUVENY, RAFAEL and POWERS, JOHN R., Set for instability: prospects for conflict and cooperation between Israel and Jordan, 25 Studies in conflict and terrorism (6) 383-401

\section{CRIMINAL LAW AND TERRORISM}

ABRAMOVSKY, ABRAHAM and EDELSTEIN, JONATHAN I., The post-Shein- bein Israeli extradition law; has it solved the extradition problems between Israel and the United States or has it merely shifted the battleground, 35 VJTL (1) 172

ARBOUR, LOUISE, War crimes and the culture of peace, University of Toronto Press , 64p.

BLUMENTHAL, DANIEL A., The politics of justice: why Israel signed the International Criminal Court Statute and what the signature means, 30 Georgia Journal of International and Comparative Law (3) 593-615

BOOT, MACHTELD, Nullum crimen sine lege and the subject matter jurisdiction of the International Criminal Court : genocide, crimes against humanity, war crimes, Antwerpen [etc.]: Intersentia 708 p.

DIENG, ADAMA, International criminal justice: from paper to practice - a contribution from the International Criminal Tribunal for Rwanda to the establishment of the International Criminal Court, 25 FILJ (3) 688-707

EBERSTADT, NICHOLAS, American security relations with Northeast Asia after 911: the doughnut and the hole, 26 Korea \& world affairs, Research Center for Peace and Unification (3) 335-356

EVERETT, DANIEL JAMES, The "war" on terrorism: do war exclusions prevent insurance coverage for losses due to acts of terrorism?, 54 Alabama Law Review (1) $175-191$

FOX, HAZEL, The International Court of Justice's Treatment of Acts of the State and in particular the attribution of acts of individuals to the state, In Liber amicorum Judge Shigeru Oda, ed. by Nisuke 
Ando, Edward McWhinney and Rudiger Wolfrum 143-163

FROWEIN, JOCHEN ABR., Provisional measures by the International Court of Justice - the LaGrand Case, 62 Zeitschrift für ausländisches öffentliches Recht und Völkerrecht (ZavRV) (1-2) 5560

GEMALMAZ, MEHMET SEMIH, The death penalty in Turkey (1920-2001): facts, truths and illusions, 13 Criminal Law Forum (1) 91-122

GREENWOOD, CHRISTOPHER, International Law and the 'war against terrorism', 78 International Affairs (2) 301-317

HENG, YEE-KUANG, Unravelling the 'war' on terrorism: a risk-management exercise in war clothing? In 33 Security dialogue (2) 227-242 International Peace Research Institute, Oslo (PRIO)

HO, THAM CHEE, Terrorist property rights in Singapore: what's left after the United Nations Act 2001, Singapore Journal of Legal Studies (July Issue) 176-213

HOR, MICHAEL, Terrorism and the criminal law: Singapore's solution; Singapore Journal of Legal Studies (July Issue) 3055

KOHONA, PALITHA T.B., The international rule of law and the role of the United Nations, 36 The International Lawyer (4) 1131-1144

KUSHA, HAMID R., The sacred law of Islam: a case study of women's treatment in the Islamic Republic of Iran's criminal justice system, Aldershot [etc.]: Ashgate $314 p$.

LAUTERPACHT, HERSCH, The revision of the Statute of the International Court of Justice: with an introduction by Sir Elihu
Lauterpacht, 1 The Law and Practice of International Courts and Tribunals (1) 55128

Legal Issues Arising from the War in Afghanistan and Related Anti-Terrorism Efforts, Human Rights Watch, electronic copy

LEVENSON, LAURIE L., Detention, material witnesses \& the war on terrorism, 35 Loyola of Los Angeles Law Review (4) 1217-1226

MACAULAY, THOMAS, A penal code prepared by the Indian Law Commissioners and published by command of the Governor General of India in Council: reprinted from the Calcutta edition, Indian penal code, Union, NJ [etc.] : Lawbook Exchange 138p.

MCCARTHY, JOSEPH R., The Third United Nations World Conference on the least developed countries: a global agenda for the new millennium, 18 New York Law School Journal of Human Rights (3) 487497

MCLAUGHLIN, ROBERT, United Nations mandated naval interdiction operations in the territorial sea 51 ICLQ (2) 249-278

MIYOSHI, MASAHIRO, Considerations of equity in maritime boundary cases before the International Court of Justice, In Liber amicorum Judge Shigeru Oda, ed. by Nisuke Ando, Edward McWhinney and Rudiger Wolfrum 1087-1101

MOORE, JOHN ALLPHIN JR. and PUBANTZ, JERRY, Encyclopedia of the United Nations, New York, NY, 484p.

POLTAK, CELESTE, Humanitarian intervention: a contemporary interpretation of the Charter of the United Nations, 60 University of Toronto Faculty of Law Review (2) 1-38 
OBATA, KAORU, The relevance of jurisdiction to deal with the merits to the power to indicate interim measures: a critique of the recent practice of the International Court of Justice In Liber amicorum Judge Shigeru Oda, ed. by Nisuke Ando, Edward McWhinney and Rudiger Wolfrum 451-462

PAUST, JORDAN J., Antiterrorism military commissions: the ad hoc DOD rules of procedure, 23 Michigan Journal of International Law (3) 677-694

RAHMDEL, MANSOUR, International judicial criminal cooperation in combating narcotic drugs crimes in Iranian law, 10 European Journal on Crime, Criminal Law Criminal Justice (4) 2943-302

RAMRAJ, VICTOR V., Terrorism, security, and rights: a new dialogue, Singapore Journal of Legal Studies, (July issue) 115

Responding to terrorism: crime, punishment, and war, 115 Harvard Law Review (4) 1217-1238

SADAT, LEILA NADYA, The International Criminal Court and the transformation of International Law: justice for the new millenium, Ardsley, NY: Transnational Publishers, Series, 566p.

SEKOLEC, JERNEJ, United Nations Commission on International Trade Law: introduction to the UNICITRAL Model Law on international commercial conciliation, 27 Yearbook of Commercial Arbitration, 398-413

SIMMA, BRUNO (ed.), The charter of the United Nations : a commentary, Oxford University Press 1405 p.

SWAN SIK, KO, The attitude of Asian states towards the International Court of Justice revisited, In Liber amicorum Judge
Shigeru Oda, ed. by Nisuke Ando, Edward McWhinney and Rudiger Wolfrum 165-176

TOCHILOVSKY, VLADIMIR, Proceedings in the International Criminal Court: some lessons to learn from ICTY experience, 10 European Journal on Crime, Criminal Law Criminal Justice (4) 268-275

YU, PING, Glittery promise vs. dismal reality: the role of a criminal lawyer in the People's Republic of China after the 1996 revision of the Criminal Procedure law, 35 VJTL (3) 827-864

\section{DECOLONIZATION AND SELF-DETERMINATION}

CARDENAS, EMILIO J. and CAQAS, MARMA FERNANDA, The limits of self-determination, in The self-determination of peoples, ed. by Wolfgang Danspeckgruber, 101-118

CHESTERMAN, SIMON, East Timor in transition: self-determination, state-building and the United Nations, In 9 International Peacekeeping (1) 45-76

DANSPECKGRUBER, WOLFGANG (ed.), The self-determination of peoples: community, nation and state in an interdependent world, Publisher: Boulder, CO, $466 p$.

DOYLE, MICHAEL W., UN intervention and national sovereignty, in The selfdetermination of peoples, ed. by Wolfgang Danspeckgruber, 67-100

FALK, RICHARD, Self-determination under International Law: the coherence of doctrine versus the incoherence of experience, in The self-determination of peoples, ed. by Wolfgang Danspeckgruber, 31-66 
FELGENHAUER, TYLER, Selected selfdetermination and interstate conflicts since 1990, in The self-determination of peoples, ed. by Wolfgang Danspeckgruber, 393-405

HANNUM, HURST, Rethinking self-determination In International Law and the rise of nations, ed. by Robert J. Beck and Thomas Ambrosio, 214-249

HERBST, JEFFREY, Global change and the future of existing nation-states, in The self-determination of peoples, ed. by Wolfgang Danspeckgruber, 13-30

KNOP, KAREN, Diversity and self-determination in International Law, Cambridge University Press, 434p.

KOHLI, ATUL, Can democracies accommodate ethnic nationalism?: the rise and decline of self-determination movements in India, in The self-determination of peoples, ed. by Wolfgang Danspeckgruber, 287-314

KRETZMER, DAVID, The occupation of justice: the Supreme Court of Israel and the Occupied Territories, State University of New York Press, 262p.

LUSTICK, IAN S., Self-determination and state contraction: Britain and Ireland, France and Algeria, Israel and the West Bank/Gaza, in The self-determination of peoples, ed. by Wolfgang Danspeckgruber, 201-226

PEI, MINXIN, Self-determination and local autonomy: reconciling conflicting interests in China, in The self-determination of peoples, ed. by Wolfgang Danspeckgruber, 315-332

RAIC, DAVID, Statehood and the law of self-determination, Kluwer Law International, 495p.

\section{DEVELOPMENT}

AL HABSY, S.N. and UPRETY, KISHOR, Cooperation for nominal development or politics for actual survival?: South Asia in the making of International Law, 12 Journal of Transnational Law \& Policy (1) $19-93$

AL-SAEED, MANSOUR, Legal protection of economic development agreements, 17 ALQ (2) 150-176

ELWELL, CHRISTINE, The role of NGOs in the development of new trade law In Looking ahead: International Law in the 21st century, ed. in chief Diane Hiscox, ed. Johanne Levasseur, 172-177

FENG, XIAOQING, A Review of the development of marriage law in the People's Republic of China, 79 University of Detroit Mercy Law Review (3) 331-398

FINGER, J. MICHAEL and SCHULER, PHILIP, Implementation of WTO commitments: the development challenge, 493-503

GIPOULOUX, FRANÇOIS, China's economic development and the WTO membership issue: stakes and strategies, in Regional and Global Regulation of International Trade, ed. by Francis Snyder, 181-192

HOEKMAN, BERNARD, MATTOO, AADITYA and ENGLISH, PHILIP (ed.), In Development, Trade and the WTO, 493-503

KAMALA, M.K., The UN development cooperation and the Third World: a study with special reference to the UNDP and India, Manak, New Delhi, 257-271

MATHIS, JAMES, International Law Association (Netherlands), working group on international trade law (NVIR): essays on 
development and the Doha agenda, 29 Legal Issues of Economic Integration (1), 41

Law and sustainable development since Rio: legal trends in agriculture and natural resources management, FAO Legal Office, Food and Agriculture Organization of the United Nations, 376p.

SAWYER, JOHN F., Shipbreaking and the North-South debate: economic development or environmental and labor catastrophe?, 20 Penn State International Law Review (3) 535-562

SCHIFF, MAURICE and WINTERS, L. ALAN, Regionalism and development: the implications of World Bank research for ACP and Latin American countries, 36 JWT (3) 479-499

SENGUPTA, ARJUN, On the theory and practice of the right to development, 24 Human Rights Quarterly (4) 837-889

SHAW, NEVIN and COSBEY, AARON, GATT, the WTO and sustainable development: positioning the work program on trade and environment, International Institute for Sustainable Development, $12 \mathrm{p}$.

SHEN, LEI, CHENG, SHENGKUI, GU, SHUZHONG and LU, YAO, Environmental policy and law for sustainable natural resources development: issues and challenges, 32 Environmental Policy Law (2) $91-98$

SHAKYA, PURNA MAN, Development and enforcement of environmental law: constitutional aspects and judicial trends, 15 NLR (1-2) 231-248

WALLACE-BRUCE, NII LANTE, Global trade and sustainable development: two steps forward in the WTO?, 35 Com- parative International Law Journal of South Africa (2) 236-255

\section{DIPLOMATIC AND CONSULAR RELATIONS}

ACEVES, WILLIAM J., International Court of Justice judgment on duty to inform detained persons of their right to consular assistance and on legal effect of provisional measures, 96 AJIL (1) 210-219

BAKER, STEPHANIE, Germany v. United States in the International Court of Justice: an international battle over the interpretation of Article Thirty-six of the Vienna Convention on Consular Relations and provisional measures orders, 30 Georgia Journal of International and Comparative Law (2) 277-304

BISHOP, ANTHONY N., The unenforceable rights to consular notification and access in the United States: what's changed since the Lagrand Case?, 25 Houston Journal of International Law (1) 1-98

DRINAN, CARA, Article 36 of the Vienna Convention on Consular Relations: private enforcement in American courts after LaGrand, 54 Stanford Law Review (6) 1303-1319

MENNECKE, MARTIN, Towards the humanization of the Viena Convention of Consular Rights: The LaGrand case before the International Court of Justice, 44 German Yearbook of International Law 430-468

SCHIFFMAN, HOWARD S., The LaGrand decision: the evolving legal landscape of the Vienna Convention on consular relations in U.S. death penalty cases, 42 Santa Clara Law Review (4) 1099-1135

WEINMAN, JENNIFER LYNNE, The clash between U.S. criminal procedure and the 
Vienna Convention on Consular Relations: an analysis of the International Court of Justice decision in the LaGrand case, 17 AUILR (4) 857-904

\section{ECONOMIC RELATIONS AND INTERNATIONAL FINANCE}

A step towards procedural certainty: amendments to China's trademark Review and adjudication rules, 16 CLP (9) 21-23

Administration of representative establishments in China of foreign-funded financial institutions procedures 3610/02.06.27, 16 CLP (6) 53-63

AL-SABAH, S.J., FEREIG, S.M. and HOARE, D.J., Construction claims: results from major tribunal findings in Kuwait, 68 Arbitration (1) 11-16

ALBERT, DAVID M., Addressing abuse of the corporate entity in the People's Republic of China: new thoughts on China's need for a defined veil piercing doctrine, 23 University of Pennsylvania Journal of International Economic Law (4) 873-897

AL-SABAH, S.J., FEREIG, S.M. and HOARE, D.J., Construction claims: results from major tribunal findings in Kuwait, 68 Arbitration (1) 11-16

BRADBROOK, ADRIAN J., Electric power interconnection in North-East Asia: towards a North-East Asian energy charter?, 20 Journal of Energy and Natural Resources Law (2) 135-143

BRANNELLY, JILL M., The United States' grant of permanent normal status to China: a recipe for tragedy or transformation?, 25 Suffolk Transnational Law Review (3) 565-585

BUTT, SIMON, Intellectual property in Indonesia: a problematic legal transplant, 24
European Intellectual Property Review (9) 429-437

CALDWELL, ROBERT, WANG, WANG and BUTTERWORTHS, The future of foreign banks in China: new administrative regulations on foreign-funded financial institutions, 17 Journal of International Banking and Financial Law (8) 324-331

CHAN, NICHOLAS H., Blueprint for China's post-WTO telecom competition framework, 15 CLP (10) 22-25

CHEN, FAYUN, Dispute resolution and the WTO, 15 CLP (10) 39-43

CHEN, LIHU and GU, YUN, China's safeguard measures under the new WTO framework, 25 FILJ(5) 1169-1186

CHENGZI, ZHENG, Looking into the revision of the trade mark and copyrights laws from the perspective of China's accession to WTO, 24 European Intellectual Property Review (6) 313-323

DELICH, VALENTINA, Developing countries and the WTO dispute settlement system In Development, trade and the WTO ed. by Bernard Hoekman, Aaditya Mattoo and Philip English, 71-80

DUDEK, MITCH and WANG, ALEX, China's accession to the WTO: ready and willing... but able?, 15 CLP (10) 18-21

DUNCAN, CHRISTOPHER, Out of conformity: China's capacity to implement World Trade Organization Dispute Settlement Body decisions after accession, 18 AUILR (2) 399-506

Establishment of fund management companies with foreign equity participation rules, 3700/02.06.01(2), 16 CLP (6) 3134 
FAYETTE, LOUISE DE LA, United States: import prohibition of certain shrimp and shrimp products: recourse to Article 21.5 of the DSU by Malaysia, 96 AJIL (3) 685-692

FINGER, J. MICHAEL and WINTERS, ALAN, Reciprocity in the WTO, in Development, Trade and the WTO, ed. by Bernard Hoekman, Aaditya Mattoo and Philip English, 50-60

FINK, CARSTEN and SMARZYNSKA, BEATA K., Trademarks, geographical indications and developing countries, in Development, Trade and the WTO, ed. by Bernard Hoekman, Aaditya Mattoo and Philip English, 403-412

GAINES, SANFORD E., International trade, environmental protection and development as a sustainable development triangle, 11 Review of European Community and International Environmental Law (3) 259-274

GAMBERALE, CARLO and MATTOO, AADITYA, Domestic regulations and liberalization of trade in services, in Development, Trade and the WTO, ed. by Bernard Hoekman, Aaditya Mattoo and Philip English, 293-303

GARAY, LUIS JORGE and CORNEJO, RAFAEL, Rules of origin and trade preferences, in Development, Trade and the WTO, ed. by Bernard Hoekman, Aaditya Mattoo and Philip English, 114-121

GEBHARDT, IMMANUEL and OLBRICH, KERSTIN, Foreign trade law in China: perspectives regarding rules of origin, 36 JWT (1) 117-127

GIPOULOUX, FRANÇOIS, China's economic development and the WTO membership issue: stakes and strategies, in Regional and Global Regulation of Inter- national Trade, ed. by Francis Snyder, 181-192

GONG, HONGLIU, Legal strategies for challenging the current EU anti-dumping campaign against imports from China: a Chinese perspective, 27 Brooklyn Journal of Int. Law (2) 575-609

GONZALEZ, CARMEN G., Institutionalizing inequality: the WTO Agreement on Agriculture, food security, and developing countries, 27 Columbia Journal of Environmental Law (2) 433-490

GUO, RICHARD QIANG, Piercing the veil of China's legal market: will GATS make China more accessible for U.S. Law firms?, 13 Indiana International and Comparative Law Review (1) 147-184

HAMNER, KENNETH J., The globalization of law: international merger control and competition law in the United States, the European Union, Latin America and China, 11 Journal of Transnational Law and Policy (2) 385-405

HARRIS, H. STEPHEN, Jr., Competition law and patent protection in Japan: a halfcentury of progress, a new millennium of challenges, 16 Journal of Asian Law (1) 74-139

HAYS, THOMAS and YUN, ZHANG, New amendments to the copyright law of the People's Republic of China, 24 European Intellectual Property Review (6) 301-312

HOEKMAN,BERNARD and SAGGI, HOEKMAN, Multilateral disciplines and national investment policies, in Development, Trade and the WTO, ed. by Bernard Hoekman, Aaditya Mattoo and Philip English, 439-469

HOLBIG, HEIKE and ASH, ROBERT, China's accession to the World Trade Organization: national and international 
perspectives, Routledge Curzon, London, New York, 319p.

HOLMES, PETER, Trade, competition and the WTO, in Development, Trade and the WTO, ed. by Bernard Hoekman, Aaditya Mattoo and Philip English, 447-455

HUANG, THOMAS WEISHING, The gathering storm of antidumping enforcement in China, 36 JWT (2) 255-283

HUDEC, ROBERT E., The adequacy of WTO dispute settlement remedies: a developing country perspective In Development, trade and the WTO ed. by Bernard Hoekman, Aaditya Mattoo and Philip English, 81-91

HUNG, VERON MEI-YING, China's WTO commitment on independent judicial Review: an opportunity for political reform, Carnegie Endowment for International Peace, 26p.

HUO, WEI, Introduction and critical analysis of anti-dumping regime and practice in China pending entry of WTO: transition toward a WTO-modeled trade legal mechanism, 36 The International Lawyer (1) $197-214$

INAMA, STEFANO, Nonpreferential rules of origin and the WTO harmonization program, in Development, Trade and the WTO, ed. by Bernard Hoekman, Aaditya Mattoo and Philip English, 122-127

JHA, VEENA, Environmental regulation and the WTO, in Development, Trade and the WTO, ed. by Bernard Hoekman, Aaditya Mattoo and Philip English, 472-481

KHEMANI, R. SHYAM, India's competition policy reforms, 30 International Business Lawyer (1) 7-13

LAIRD, SAM, Market access issues and the WTO: an overview, in Development,
Trade and the WTO, ed. by Bernard Hoekman, Aaditya Mattoo and Philip English, 97-104

LAM, JOSEPH and WONG, JAMES, FIE bankruptcy legal framework clarified by the new judicial rules in the People's Republic of China, 18 Journal of International Banking Law (2) 82-87

NOURAEE, LAYLA, Reassessing U.S. policy toward Iran: stimulating reform through economic means, 25 Suffolk Transnational Law Review (3) 535-563

LEE, BOONG-KYU, Don Quixote or Robin Hood?: minority shareholder rights and corporate governance in Korea, 15 Journal of Asian Law (2) 345-371

\section{LEHMAN, EDWARD EUGENE,} OJANSIVU, CAMILLA and ABRAMS, STAN, Well-known trademark protection in the People's Republic of China: evolution of the system, 26 FILJ(2) 257-273

LI, YAHONG, Pushing for greater protection: the trend toward greater protection of intellectual property in the Chinese software industry and the implications for rule of law in China, 23 University of Pennsylvania Journal of International Economic Law (4) 637-661

LIN, HARRY, Going public: new rules allow listing of FIEs, 15 CLP (10) 96-98

LOW, T.S., NETTO, ANNE M., and TAN, EUGENE, Tan Rail procurement: the Singapore experience, 19 The International Construction Law Review (1) 53-67

MANN, CATHERINE L., Electronic commerce, the WTO and developing countries, in Development, Trade and the WTO, ed. by Bernard Hoekman, Aaditya Mattoo and Philip English, 315-325 
MIRGHANI, HASSAN, Flight of the "Tabuk": the right of subrogation in salvage claims involving state responsibility, The Journal of Business Law (January Issue) 67-75

New rules on JV securities companies: a limited opening of China's securities industry, 16 CLP (6) 49-51

PENNA, FRANK J. and VISSER, COENRAAD J., Cultural industries and intellectual property rights, in Development, Trade and the WTO, ed. by Bernard Hoekman, Aaditya Mattoo and Philip English, 390-402

PRC administration of foreign-funded financial institutions regulations implementing rules 3610/02.01.29, 16 CLP (3) 77-111

PRC, copyright law (revised), 15 CLP (10) 53-70

PRC, trademark law (2nd revision), 15 CLP (10) $75-89$

Promise kept: the CSRC opens the door to foreign investment in fund management companies, 16 CLP (6) 35-40

QINGJIANG, KONG, China and the WTO: a legal perspective, World Scientific Publishing, 180p.

SCHIPANI, CINDY A. and LIU, JUNHAI, Corporate governance in China: then and now, Columbia Business Law Review (1) $1-69$

SCHWARZWALDER, BRIAN, et al., An update on China's rural land tenure reforms: analysis and recommendations based on a seventeen-province survey, 16 Journal of Asian Law (1) 141-225

SHEN, WILL WEI, China's regulatory scheme of online advertising and foreign investment, 30 International Business Lawyer (9) 394-403

SIEFKAS, JULIE, Copyright piracy in Vietnam: the impediments of weak enforcement policies on the country's economic reform, 14 Florida Journal of International Law (3) 475-501

SMYTH, RUSSELL, "Equity for debt swaps" in China's state-owned enterprises: a property rights perspective, 16 China Inf. (1) $1-24$

SNYDER, FRANCIS (ed.), Regional and global regulation of international trade, Oxford [etc.]: Hart, Studies in European Law and Integration, 304p.

SUBRAHMANYAN, ARJUN, China's legal scene: reform and the race for business, 16 CLP (5) 18-27

SUBRAMANIAN, ARVIND, Proprietary protection of genetic resources and traditional knowledge, in Development, Trade and the WTO, ed. by Bernard Hoekman, Aaditya Mattoo and Philip English, 382389

TARR, DAVID G., Arguments for and against uniform tariffs, in Development, Trade and the WTO, ed. by Bernard Hoekman, Aaditya Mattoo and Philip English, 526-534

TAY, SIMON, Trade and labor: text, institutions and context, in Development, $\mathrm{T}$ trade and the WTO, ed. by Bernard Hoekman, Aaditya Mattoo and Philip English, 463471

Time to honour China's WTO commitments: MOJ issues implementing rules regarding foreign law firms, 16 CLP (8) 33-36

TUSSIE, DIANA and LENGYEL, MIGUEL F., Developing countries: turning participation into influence, in Development, 
Trade and the WTO, ed. by Bernard Hoekman, Aaditya Mattoo and Philip English, 485-492

VAUGHN, CHRISTOPHER M., Venture capital in China: developing a regulatory framework, 16 Journal of Asian Law (1) 227-252

WALKER, GORDON and REID, TERRY, Upgrading corporate governance in East Asia: part 1, 17 Journal of International Banking Law (3) 59-66

WANG, LEI and YU, SHENGXING, China's new anti-dumping regulations: improvements to comply with the World Trade Organization rules, 36 JWT (5) 903-920

WANG, XIAOLING, Shipowners' liens on cargo in China, 33 Journal of Maritime Law Commerce (2) 217-232

WEI, XINJIANG, Asset management company and debit-equity swap practice in China, 17 Journal of International Banking Law (10) 295-300

WEIPING, HUANG, China's Trade Policy and its implications In Regional and global regulation of international trade, ed. by Francis Snyder, 245-262

WILKINSON, MARGARET ANN, The challenges of coping with intellectual property regime implementation: observations on Canada and Vietnam, 16 Intellectual Property Journal (1) 45-92

WILLIAMS, MARK, YUK-CHOI, KONG and YAN, SHEN, Bonanza or mirage?: textiles and China's accession to the WTO, 36 JWT (3) 577-591

WILSON, JOHN S., Standards, regulation and trade: WTO rules and developing country concerns, in Development, Trade and the WTO, ed. by Bernard Hoekman,
Aaditya Mattoo and Philip English, 428438

YU, LEI, Rule of law or rule of protectionism: anti-dumping pratices toward China and the WTO dispute settlement system, 15 Journal of Asian Law (2) 293-343

ZHOU, JESSICA JIONG, Trademark law \& enforcement in China: a transnational perspective, 20 Wisconsin International Law Journal (2) 415-444

ZHOU, ZHONGFEI and LI, JINGWEI, In search of approaches to improving corporate governance in China's state-owned commercial banks, 36 The International Lawyer (1) 215-235

\section{ENVIRONMENT}

ADHIKARI, PRAVAKAR, Environmental protection issues related to civil aviation, 15 NLR (1-2) 130-143

ARYAL, RAVI SHARMA, The Convention on International Trade in Endangered Species of Wild Fauna and Flora (CITES) $\&$ Nepalese position, 15 NLR (1-2) 220230

BADENOCH, NATHAN, Transboundary environmental governance: principles and practice in Mainland Southeast Asia, World Resources Institute, Washington D.C., 33p.

BHATTARAI, ANANDA MOHAN, Protected areas and issues of displacement, resettlement \& rehabilitation: a case study of Royal Shuklaphant Wildlife reserve, 15 NLR (1-2) 57-88

BHUTANI, SHALINI and KOTHARI, ASHISH, The biodiversity rights of developing nations: a perspective from India, 32 Golden Gate University Law Review (4) 587-627 
CHIRCOP, ALDO, Ships in distress, environmental threats to coastal states, and places of refuge: new directions for an Ancien Regime?, 33 OCDIL(2) 207-226

CHUDAL, KUMAR, Convention on biological diversity: some thorniest issues for developing countries, 15 NLR (1-2) 144158

CRAIG, DONNA G., ROBINSON, NICHOLAS A. and KHENG-LIAN, $\mathrm{KOH}$ (ed.), Capacity building for environmental law in the Asian and Pacific region: approaches and resources, Asian Development Bank, Manila, 261-271

DHAKAL, RAM BABUL, Efforts towards protection of environment under SAARC, 15 NLR (1-2) 266-276

DZIDZORNU, DAVID M., environment protection under the regional conventions: limits to the contribution of procedural norms, 33 OCDIL(3-4) 263-316

FERRIS, RICHARD J. JR. and ZHANG, HONGJUN, The challenges of reforming an environmental legal culture: assessing the status quo and looking at post-WTO admission challenges for the People's Republic of China, 14 GIELR (3) 429460

GEORGE, MARY, Transit passage and pollution control in straits under the 1982 Law of the Sea Convention, 33 OCDIL (2) $189-205$

HELTZER, GREGORY E., Stalemate in the Aral Sea Basin: will Kyrgyzstan's new water law bring the downstream nations back to the multilateral bargaining table?, 15 GIELR(2) 291-320

KARKI, SUSHIL B., Water pollution control laws and judicial approach: Nepalese scenario 15 NLR (1-2) 330-353
KEYUAN, ZOU, Governing marine scientific research in China, 34 OCDIL (1) 1-28

KHANAL, SHAMBHU PRASAD, Conservation of forest: policies and legislation with regards to environmental protection in Nepal, 15 NLR (1-2) 249-265

KHATRI, NRISHIMA KUMAR, Conservation of bio-diversity as natural heritage: an analysis of legal aspect of Nepal, 15 NLR (1-2) 277-294

LHUNDUP, SHERA, The genesis of environmental ethics and sustaining its heritage in the Kingdom of Bhutan, 14 GIELR (4) 693-739

LIN, CATHERINE K., YAN, LINAN, and DAVIS, ANDREW, Globalization, extended producer responsibility and the problem of discarded computers in China: an exploratory proposal for environmental protection, 14 GIELR (3) 525-576

MENSAH, THOMAS A., Civil liability and compensation for vessel-source pollution of the marine environment and the United Nations Convention on the Law of the Sea (1982), in Liber amicorum Judge Shigeru Oda, ed. by Nisuke Ando, Edward McWhinney and Rudiger Wolfrum, 1391-1434

MUSHKAT, RODA, Public participation in environmental law making: a comment on the international legal framework and the Asia-Pacific perspective, 1 CJIL (1) 185-224

PANT, AMBER PRASAD, International environmental governance and the implementation of environmental treaties in Nepal: an overview, 15 NLR (1-2) 15-56

PICKLES, MICHAEL, Implementing ecologically sustainable development in China: the example of Heilongjiang 
Provence, 14 The Georgetown International Environmental Law (3) 577-592

POKHAREL, DINA MANI, National compliance of convention on biological diversity in Nepal, 15 NLR (1-2) 295-329

PRADHANANGA, RAJIT BHAKTA, Criminalization of environmental violations and Nepalese environmental legislations: a critical study, 15 NLR (1-2) 106-129

QUAN, RUIXUE, Establishing China's environmental justice study models, 14 GIELR (3) 461-487

RIJAL, RAMESH PRASAD, Biodiversity and its conservation in Nepal: legal perspective, 15 NLR (1-2) 354-367

SAPKOTA, TARA PRASAD, Participatory policy process: an effective mechanism of environmental management for Nepal, 15 NLR (1-2) 168-205

SAUNDERS, J. OWEN, Transboundary water management and the development of international environmental and resources law, in Looking Ahead: International Law in the 21st century, ed. in chief, Diane Hiscox and ed. Johanne Levasseur, 200-210

SHAKYA, PURNA MAN, Development and enforcement of environmental law: constitutional aspects and judicial trends, 15 NLR (1-2) 231-248

SIJAPATI, BIJAY SINGH, Role of environmental impact assessment under international and Nepalese legislation, 15 NLR (1-2) 206-219

SUBEDI, SURYA P., Regulation of shared resources in International Law: the challenge of balancing competing demands, 15 NLR (1-2) 1-14
TAO, BETSY, A stitch in time: addressing the environmental, health, and animal welfare effects of China's expanding meat industry, 15 GIELR (2) 321-357

THAPA, SITA MAIYA SINGH, Air or atmosphere as life force: legal remedies for living beings from the polluted air in Nepal, 15 NLR (1-2) 89-105

VAN DYKE, JON M., The legal regime governing sea transport of ultrahazardous radioactive materials, 33 OCDIL (1) 77 108

VAN WYK, CHRISTOPHER, The role of equity in environmental protection in the People's Republic of China: a Review of "environmental protection in China: institutions, enforcement, and compliance", 14 GIELR (3) 593-605

WATTERS, LAWRENCE and XI, WANG, The protection wildlife and endangered species in China, 14 GIELR (3) 489-524

\section{GENERAL}

FRY, JAMES D., Islamic law and the IranUnited States Claims Tribunal: the primacy of International Law over municipal law, 18 Arbitration International (2) 105123

GOH, BEE CHEN, Law without lawyers, justice without courts: on traditional Chinese mediation, Ashgate, 149p.

HASSAN, FAROOQ, Religious liberty in Pakistan: law, reality, and perception (a brief synopsis), 2002 Brigham Young University Law Review (2) 283-299

HEUSER, ROBERT, China and developments in International Law: Wang Tieya as a contemporary, 4 Journal of the History of International Law (1) 142-158 
HOLMES, JOHN, End the Moratorium: The Timor Gap Treaty as a model for the complete resolution of the Western Gap in the Gulf of Mexico, 35 VJTL (3) 925952

JAIN, H.M., International law and international politics: a study in mutual interactions, 58 India Quarterly (1) 75-104

JAMAL, ARIF A., Principles in the development of Ismaili law, 7 Yearbook of Islamic Middle East. Law, 115-126

JOHNSON, KAY, Politics of international and domestic adoption in China, 36 Law and Society Review (2) 379-396

KEYUAN, ZOU, Judicial reform in China: recent developments and future prospects, 36 The International Lawyer (3) 10391062

KWAN SIK, KO, Wang Tieya and International Law in Asia, 4 Journal of the History of International Law (1) 159-165

LAI, ALAN, Building public confidence in anti-corruption efforts: approach of the Hong Kong Special Administrative Region of China, 2 Forum on crime and society (1) United Nations, Centre for International Crime Prevention, 135-146

LEE, ERIC YONG-JOONG, Early development of modern International Law in East Asia - with special reference to China, Japan and Korea, 4 Journal of the History of International Law (1) 42-76

LIM, C.L., Executive lawmaking in compliance of international treaty, Singapore Journal of Legal Studies (July Issue) 73103

LIU, CHARLES CHAO, China's lawyer system: dawning upon the world through a tortuous process, 23 Whittier Law Review (4) 1037-1098
PAUST, JORDAN J., Sanctions against nonstate actors for violations of International Law, 8 ILSA Journal of International \& Comparative Law (2) 417-429

PEERENBOOM, RANDALL, China's long march toward rule of law, Cambridge University Press, 673p.

PEERENBOOM, RANDALL, Let one hundred flowers bloom, one hundred schools contend: debating rule of law in China, 23 Michigan Journal of International Law (3) $471-544$

WANG, ZHENMIN, Legal education in contemporary China, 36 The International Lawyer (4) 1203-1212

ZHANG, MO, International civil litigation in China: a practical analysis of the Chinese judicial system, 25 Boston College International and Comparative Law Review (1) 59-96

12. INDIVIDUALS, GROUPS OF PERSONS - HUMAN RIGHTS

AZNAR-GSMEZ, MARIANO J., A decade of human rights protection by the UN Security Council: a sketch of deregulation?, 13 EJIL (1) 223-241

BONGIORNO, CARLA, A culture of impunity: applying international human rights law to the United Nations in East Timor, 33 Columbia human rights law Review (3) 623-692

CHAN, STEVE, Human rights in China and the United States: competing visions and discrepant performances, 24 Human rights quarterly (4) 1035-1053

FARRELL, KENAN, Where have all the young girls gone?: preconception gender selection in India and the United States, 
13 Indiana International and Comparative Law Review (1) 253-281

FELD, LOUISE, Along the spectrum of women's rights advocacy: a cross-cultural comparison of sexual harassment law in the United States and India, 25 FILJ(5) 1205-1281

FENG, XIAOQING, A Review of the development of marriage law in the People's Republic of China, 79 University of Detroit Mercy Law Review (3) 331-398

GARDNER, PAIGE, The Conference on Sustainable Food Security for All by 2020 concedes that goal in unlikely, 2001 Colorado Journal of International Environmental Law and Policy, 81-88

HUI, PATRICK T.C., Birth control in China: cultural, gender, socio-economic and legislative perspectives in light of CEDAW standards, 32 Hong Kong Law Journal (1) 187-205

KAPLAN, YEHIEL S., The right of a minor in Israel to participate in the decisionmaking process concerning his or her medical treatment, 25 FILJ(5) 1085-1168

KAUR, JASKARAN, A judicial blackout: judicial impunity for disappearances in Punjab, India, 15 Harvard Human Rights Journal (Spring Issue) 269-300

LOUCAIDES, LOUKIS G., The judgment of the European Court of Human Rights in the case of Cyprus v. Turkey, 15 LJIL(1) 225-236

MAINKA, SUE and TRIVEDI, MANDAR, Links between biodiversity conservation, livelihoods and food security: the sustainable use of wild species for meat, Gland [etc.], International Union for Conservation of Nature and Natural Resources, 135p.
NADER, FADI B., Kuwait: human rights under the Constitution, 7 Yearbook of Islamic Middle East. Law, 267-270

NEARY, IAN, Human rights in Japan, South Korea and Taiwan, Routledge, London, 297p.

NISHIGAI, MAKOTO, The comfort women case in the United States: a note on questions resolved and unresolved in Hwang v. Japan, the first lawsuit brought by Asian women against Japan for war crimes, 20 Wisconsin International Law Journal (2) 371-395

PAUST, JORDAN J., Human rights responsibilities of private corporations, $35 \mathrm{VJTL}$ (3) $801-825$

RAMCHARAN, BERTRAND G., The Security Council and the protection of human rights, Nijhoff Publishers, 246p.

Sustainable food security for all by 2020 : proceedings of an international conference, 4-6 September 2001, Bonn, Germany, International Food Policy Research Institute, 281p.

SVENSSON, MARINA, Debating human rights in China: a conceptual and political history, Lanham, MD: Rowman \& Littlefield, 389p.

YOUM, KYU HO, Freedom of expression and the law: rights and responsibilities in South Korea, 38 Stanford Journal of International Law (1) 123-151

\section{INFORMATION AND COMMUNICATION}

BETH, ULRIKA, Access to information v. intellectual property rights, 24 European Intellectual Property Review (3) 138-146 
CARMICHAEL, PATRICK, Information interventions, media development and the Internet, in Forging Peace, ed. by Price, Monroe E. and Mark Thompson, 365-392

DAI, XINYUAN, Information systems in treaty regimes, 54 World Politics (4) 405436

DAMANIA, FARZAD, The Internet: equalizer of freedom of speech on the Internet in the United States and India, 12 Indiana International and Comparative Law Review (2) 243-264

DARBISHIRE, HELEN, Non-governmental perspectives: media freedom versus information intervention, in Forging Peace, ed. by Price, Monroe E. and Mark Thompson, 329-364

GREGORY, PHILIP, STEINERT, Tim and Yun, Zhou, New disclosure standards for FICLS prospectuses, 16 CLP (4) 41-43

GROSSMAN, ANDREW, Towards cooperation in access to foreign primary law, 30 International Journal of Legal Information (1) $1-52$

GRUNDMANN, STEFAN, Information, party autonomy and economic agents in European Contract Law, 39 Common Mark. Law Review (2) 269-293

JOHNSON, PHILLIP A., Is it time for a treaty on information warfare? in Computer Network Attack and International Law, ed. by Michael N. Schmitt and Brian T. O'Donnell, 439-455

KUEHL, DANIEL T., Information operations, information warfare, and computer network attack: their relationship to national security in the information age, in Computer Network Attack and International Law, ed. by Michael N. Schmitt and Brian T. O’Donnell, 35-58
MARSTON, JOHN, Neutrality and the negotiation of an information order in Cambodia, in Forging Peace, ed. by Price, Monroe E. and Mark Thompson, 177-200

MERTUS, JULIE, Note on legality of information intervention, in Forging Peace, ed. by Price, Monroe E. and Mark Thompson 259-286

MURRAY, DANIEL R., CHORVAT, TIMOTHY J. and O'CONNOR, CHRISTOPHER M., Problems of proof in a paperless world: electronic information as evidence in commercial litigation, 35 Uniform Commercial Code Law Journal (1) 1-30

PORAT, IDDO and ROSEN-ZVI, ISSACHAR, Who's afraid of Channel $\&$ ?: ideological radio and freedom of speech in Israel, 38 Stanford Journal of International Law (1) 79-95

ROWE, HEATHER, Examining the current position on cross-border information transfers: in theory and in practice, part 3, 17 Butterworths Journal of International Banking and Financial Law (6) 249-254

RUI, KANG and XIAOJU, FENG, A challenge to emerging economies: new competition patterns required in the telecommunications industry: the case of China after its entry into the WTO, 36 The International Lawyer (4) 1173-1184

SARTORI, ANNE E., The might of the pen: a reputational theory of communication in international disputes, 56 International Organization (1) 121-149

TAYLOR, PHILIP M., Information warfare and information intervention, in Forging Peace, ed. by Price, Monroe E. and Mark Thompson, 313-328 
WIMHURST, DAVID, Preparing a plebiscite under fire: the United Nations and public information in East Timor, in Forging Peace, ed. by Price, Monroe E. and Mark Thompson, 287-309

ZEDALIS, REX J., Government participation or acquiescence in trade-affecting consumer information: does culpability arise under the GATT?, 49 Netherlands International Law Review (2) 227-251

14. PEACE-KEEPING, PEACEMAKING AND PEACEBUILDING

CHESTERMAN, SIMON, East Timor in transition: self-determination, state-building and the United Nations, 9 International Peacekeeping (1) 45-76

DONALD, DOMINICK, Neutrality, impartiality and UN peacekeeping at the beginning of the 21st century, 9 International Peacekeeping (4) 21-38

JEONG, HO-WON (ed.), Approaches to peacebuilding, Basingstoke: Palgrave Macmillan, 203p.

LEDERACH, JOHN PAUL and JENNER, JANICE MOOMAW (eds.), A handbook of international peacebuilding: into the eye of the storm, Jossey-Bass, San Francisco, 336p.

PEOU, SORPONG, The UN, peacekeeping, and collective human security: from an agenda for peace to the Brahimi Report, 9 International Peacekeeping (2) 51-68

RYAN, ALAN, The strong lead-nation model in an ad hoc coalition of the willing: Operation Stabilise in East Timor, 9 International Peacekeeping (1) 23-44

SCHNABEL, ALBRECHT, Post-conflict peacebuilding and second-generation preventive action, 9 International Peacekeeping (2) 7-30

\section{PEACEFUL SETTLEMENT OF} INTERNATIONAL DISPUTES

AL-SAMAAN, YALHA, Dispute resolution in Saudi Arabia, 7 Yearbook of Islamic Middle East Law 71-84

ANTONIADIS, ANTONIS, Enhanced third party rights in the WTO Dispute Settlement Understanding, 29 Legal Issues of Economic Integration (3) 285-304

BERNARDEZ, SANTIAGO TORRES, Bilateral, plural and multipartite elements in international judicial settlement, in Liber amicorum Judge Shigeru Oda, ed. by Nisuke Ando, Edward McWhinney and Rudiger Wolfrum, 995-1007

BOISSON DE CHAZOURNES, LAURENCE, ROMANO, CESARE P.R. and MACKENZIE, RUTH (eds) International organizations and international dispute settlement: trends and prospects, Transnational, Ardsley, New York, 283p.

BUSCH, MARC L. and REINHARDT, ERIC, Testing international trade law: empirical studies of GATT/WTO dispute settlement, in The Political Economy of International Trade Law, ed. by Daniel L.M. Kennedy and James D. Southwick, 457-481

CHARNOVITZ, STEVE, Judicial independence in the World Trade Organization In International organizations and international dispute settlement, ed. by Laurence Boisson de Chazournes, Cesare P.R. Romano, Ruth Mackenzie, 219-240

DAVEY, WILLIAM J., A permanent panel body for WTO dispute settlement: desirable or practical? In The Political Economy of International Trade Law, ed. by 
Daniel L.M. Kennedy and James D. Southwick, 496-527

DUNCAN, CHRISTOPHER, Out of conformity: China's capacity to implement World Trade Organization Dispute Settlement Body decisions after accession, 18 AUILR (2) 399-506

FERRAO, PETER, Developing a system of dispute settlement for commercial activities in outer space, 68 Arbitration (3) 250-252

FUDALI, CEZARY, A critical analysis of the WTO dispute settlement mechanism: its contemporary functionality and prospects, 49 Netherlands International Law Review (1) 39-80

HAVEL, BRIAN F., International instruments in air, space and telecommunications law: the need for a mandatory supranational dispute settlement mechanism, in Arbitration in Air, Space and Telecommunications Law, ed. by the International Bureau of the Permanent Court of Arbitration, 11-57

HUDEC, ROBERT E., The adequacy of WTO dispute settlement remedies: a developing country perspective, in Development, Trade and the WTO, ed. by Bernard Hoekman, Aaditya Mattoo and Philip English, 81-91

KENNEDY, DANIEL L.M. and SOUTHWICK, JAMES D., The appellate body and its contribution to WTO dispute settlement, in The Political Economy of International Trade Law, ed. by Debra P. Steger, 482-495

KOST, INGRID, Books and articles in the field of the prevention and peaceful settlement of international disputes published in 2001-2002, 15 LJIL(2) 471-482
MARCEAU, GABRIELLE, WTO dispute settlement and human rights, 13 EJIL, Vol. (4) 753-814

NOLL, ALFONS A.E., The various approaches to dispute settlement concerning international telecommunications, in Arbitration in Air, Space and Telecommunications Law, ed. by the International Bureau of the Permanent Court of Arbitration, 161-192

PETERS, ANNE, Cooperation in international dispute settlement In International Law of cooperation and state sovereignty, ed. By Jost Delbröck, 107162

PALMETER, DAVID and ALEXANDROV, STANIMIR A., "Inducing compliance" in WTO dispute settlement, in The Political Economy of International Trade Law, ed. by Daniel L.M. Kennedy and James D. Southwick, 646-666

PAUWELYN, JOOST, The use of experts on WTO dispute settlement, 51 ICLQ (2) 325-364

RAESCHKE-KESSLER, Hilmar, Making arbitration more efficient: settlement initiatives by the arbitral tribunal, 30 IBL (4) $158-164$

SHANKER, DAYA, The Vienna Convention on the law of treaties, the dispute settlement system of the WTO and the Doha Declaration on the TRIPs Agreement, 36 JWT (4) 721-772

TIMURA, CHRISTOPHER T., Cross-examining expertise in the WTO dispute settlement process, 23 Michigan Journal of International Law (3) 709-732

TOMUSCHAT, CHRISTIAN, The 1928 general act for the pacific settlement of international disputes revisited, in Liber amicorum Judge Shigeru Oda, ed. by 
Nisuke Ando, Edward McWhinney and Rudiger Wolfrum, 977-994

TREBILCOCK, MICHAEL and SOLOWAY, JULIE, International trade policy and domestic food safety regulation: the case for substantial deference by the WTO dispute settlement body under the SPS Agreement, in The Political Economy of International Trade Law, ed. by Daniel L.M. Kennedy and James D. Southwick, 537-574

TREVES, TULLIO, International organizations as parties to contentious cases: selected aspects In International organizations and international dispute settlement, ed. by Laurence Boisson de Chazournes, Cesare P.R. Romano and Ruth Mackenzie, 37-46

TREVES, TULIO, Preliminary proceedings in the settlement of disputes under the United Nations Law of the Sea Convention: some observations, in Liber amicorum Judge Shigeru Oda, ed. by Nisuke Ando, Edward McWhinney and Rudiger Wolfrum, 749-761

WAINCYMER, JEFF, WTO litigation: procedural aspects of formal dispute settlement, Cameron May, London, 935p.

YU, LEI, Rule of law or rule of protectionism: anti-dumping practices toward China and the WTO dispute settlement system, 15 Journal of Asian Law (2) 293-343

ZEKOS, GEORGIOS I., Arbitration as a dispute settlement mechanism under UNCLOS, the Hamburg Rules, and WTO, 19 JIA (5) 497-504

\section{SEA, RIVERS AND WATER- RESOURCES}

BECKMAN, ROBERT C., Combating piracy and armed robbery against ships in
Southeast Asia: the way forward, 33 OCDIL(3-4) 317-341

KEYUAN, ZOU, Governing marine scientific research in China, 34 OCDIL (1) 1-28

LAWRENCE JUDA, Rio plus ten: the evolution of international marine fisheries governance, 33 OCDIL (2) 109-144

LI, K.X. and INGRAM, C.W.M., Maritime law and policy in China, London: Cavendish, 211p.

ONG, DAVID, The new Timor Sea Arrangement 2001: is joint development of common offshore oil and gas deposits mandated under International Law?, 17 International Journal of Maritime Coastal Law (1) $79-122$

PISANI, CHRISTIAN, Fair at sea: the design of a future legal instrument on marine bunker fuels emissions within the climate change regime, 33 OCDIL(1) 57-76

PRIDAUX, MARGI, Discussion of a regional agreement for small cetacean conservation in the Indian Ocean, 32 California Western International Law Journal (2) 211-251

VALENCIA, MARK J. and LEE, YONG HEE, The South Korea-Russia-Japan fisheries imbroglio, 26 Mar. Policy (5) 337-343

VAN DYKE, JON M., North-East Asian seas - conflicts, accomplishments and the role of the United States, 17 International Journal of Maritime Coastal Law (3) 397421

WANG, GEORGE Y.B., China's rules on shipping: sailing on an international voyage, 16 CLP (3) 31-34

\section{STATES AND GROUPS OF}




\section{STATES}

AKRAM, SUSAN M., Palestinian refugees and their legal status: rights, politics, and implications for a just solution, 31 Journal of Palestine Studies (3) 36-51

AMBROSIO, THOMAS, Irredentism: selfdetermination and interstate war In International Law and the rise of nations ed. by Robert J. Beck and Thomas Ambrosio, 284-312

ARBOUR, LOUISE, War crimes and the culture of peace, University of Toronto Press, 64p.

ARNOLD, ROBERTA, The development of the notion of war crimes in non-international conflicts through the jurisprudence of the UN ad hoc tribunals, 15 Humanitäres Völkerrecht (3) 134-142

ASSELIN, PIERRE, A bitter peace: Washington, Hanoi, and the making of the Paris Agreement, University of North Carolina Press, 272p.

ATACK, IAIN, Ethical objections to humanitarian intervention, 33 Security Dialogue (3) $279-292$

ATEBA, BERTRAND, The decline of China's communist ideology, 80 Revue de droit international, de sciences diplomatiques et politiques (3) 265-284

BAKSHI, G.D., Afghanistan: the first faultline war, (Second edn) with postscript on America's war on terrorism, Lancer, New Delhi, 256p.

BALL, HOWARD, War crimes and justice: a reference handbook, Santa Barbara, CA, 259 p.

BANTEKAS, ILIAS, Principles of direct and superior responsibility in international humanitarian law, Manchester University Press, 162p.

BASSIOUNI, M. CHERIF, Accountability for violations of international humanitarian law and other serious violations of human rights, in Post-conflict Justice, ed. by M. Cherif Bassiouni, 3-54

BLANK, LAURIE R., The role of international financial institutions in international humanitarian law: Report from the International humanitarian law working group, United States Institute of Peace: Washington, 1217-1226

BOTHE, MICHAEL, Legal restraints on targeting: protection of civilian population and the changing faces of modern conflicts, 31 Israeli Yearbook of Human Rights, 35-49

BOTHE, MICHAEL AND MARAUHN, THILO, UN administration of Kosovo and East Timor: concept, legality and limitations of Security Council-mandated trusteeship administration, in Kosovo and the International Community, ed. by Christian Tomuschat, 217-242

BOUCHET-SAULNIER, F., The practical guide to humanitarian law, (ed. and transl. from the French by Laura Brav) (First English language edition), Lanham, MD, 489p.

BRADLOW, DANIEL D., Should the international financial institutions play a role in the implementation and enforcement of international humanitarian law?, 50 University of Kansas Law Review (4) 695-729

BUCKLEY, AARON J., The conflict in Cambodia and post-conflict justice, in Post-conflict Justice, ed. by M. Cherif Bassiouni, 635-657 
BURGESS, J. PETER, Ethics of humanitarian intervention: the circle closes, 33 Security Dialogue (3), 261-264

CAPLAN, RICHARD, A new trusteeship?: the international administration of wartorn territories, Oxford University Press, $341 \mathrm{p}$.

CAPLOW, THEODORE and HICKS, LOUIS, Systems of war and peace (Second edn), Lanham MD, University Press of America, 271p.

CHAMBOVEY, DIDIER, How the expiry of the Peace Clause (Article 13 of the WTO Agreement on Agriculture) might alter disciplines on agricultural subsidies in the WTO framework, 36 JWT (2) 305-352

CHARLESWORTH, HILARY AND WOOD, MARY, Women and human rights in the rebuilding of East Timor, 71 Nordic Journal of International Law (2) 225-348

CHESTERMAN, SIMON, Legality versus legitimacy; humanitarian intervention, the Security Council, and the rule of law, 33 Security Dialogue (3), 293-307

COCKAYNE, JAMES, Islam and international humanitarian law: from a clash to a conversation between civilizations, 84 Revue Int. Croix-Rouge 1999 (847) 597-626

COLLIER, PAUL AND SAMBANIS, NICHOLAS, Understanding civil war: a new agenda, 46 Journal of Conflict Resolution (1) 3-12

CRYER, ROBERT, The fine art of friendship: jus in bello in Afghanistan, 7 JCSL (1) $37-83$

DINSTEIN, YORAM, Legitimate military objectives under the current jus in bello, 31 Israeli Yearbook of Human Rights, 134
DIXIT, J.N., India-Pakistan in war \& peace, Routledge, London, 514p.

DIXON, CLAUDIA KELLY, Nowhere to run, nowhere to hide: how the events of September 11, 2001, have impacted the refugee humanitarian crisis in Afghanistan, Colorado Journal of International Environmental Law and Policy, 111-117

DOSMUKHAMEDOV, E. K., Foreign direct investment in Kazakhstan: politico-legal aspects of post-communist transition, Basingstoke, Palgrave Macmillan, 239p.

DOUGHERTY, SEAN M., and MCGUCKIN, ROBERT H., Federalism and the impetus for reform in China, 16 CLP (4) 30-34

DRAPER, MATTHEW, Justice as a building block of democracy in transnational societies: the case of Indonesia, 40 Columbia Journal of Transnational Law (2) $391-418$

FAUSTO POCAR, Protocol I additional to the 1949 Geneva Conventions and customary International Law, Israeli Yearbook of Human Rights, vol. 31, page 145-159

Filling the vacuum: prerequisites to security in Afghanistan (report of the Consortium for Response to the Afghanistan Transition, March 2002), 17 Connecticut Journal of International Law (3) 473-532

FINDLAY, TREVOR, The use of force in UN peace operations, Oxford University Press, 486p.

FISCHBACH, MICHAEL R., The United Nations and Palestinian refugee property compensation, 31 Journal of Palestine Studies (2) 34-50

FOROUGHI, PAYAM, Tajikistan: nationalism, ethnicity, conflict, and socio-eco- 
nomic disparities: sources and solutions, 22 J. Muslim Minority Affairs (1) 39-61

FORT, TIMOTHY L. and SCHIPAN, CINDY A., The role of the corporation in fostering sustainable peace, $35 \mathrm{VJTL}$ (2) $389-436$

GASSER, HANS-PETER, Acts of terror, "terrorism" and international humanitarian law, 84 Revue Int. Croix-Rouge 1999 (847) 547-570

GUILHENNO, JEAN-MARIE, On the challenges and achievements of reforming UN peace operations, 9 International Peacekeeping (2) 69-80

HAMPSON, FRANCOISE, Women and humanitarian law, in The Human Rights of Women: International Instruments and African Experiences, ed. by Wolfgang Benedek, Esther M. Kisaakye and Gerd Oberleitner, 173-209

HOFFMAN, MICHAEL H., Quelling unlawful belligerency: the judicial status and treatment of terrorists under the laws of war, 31 Israeli Yearbook of Human Rights, 161-181

HOFFMAN, MICHAEL H., Terrorists are unlawful belligerents, not unlawful combatants: a distinction with implications for the future of international humanitarian law, 34 Case Western Reserve Journal of International Law (2) 227-230

HUSTON, MEREDITH DUBARRY, Wartime environmental damages: financing the cleanup, 23 University of Pennsylvania Journal of International Economic Law (4) 899-929

JENKINS, CATHERINE, A truth commission for East Timor: lessons from South Africa?, 7 JCSL(2) 233-251
JIA, BING BING, "Protected property" and its protection in international humanitarian law, 15 LJIL(1) 131-153

JUAN, MICHELLE ANN U., Testing the legality of the attack on Afghanistan, Ateneo Law Journal, 499-551

KALINAUSKAS, MIKAS, The use of international military force in arresting war criminals: the lessons of the International Criminal Tribunal for the Former Yugoslavia, 50 University of Kansas Law Review (2) 383-429

KAM, KARMEN, Right of abode cases: the judicial independence of the Hong Kong special administrative region $\mathrm{v}$. the sovereignty interests of China, 27 Brooklyn Journal of International Law (2) 611-637

KELLY, MICHAEL J., Understanding September 11th - an international legal perspective on the war in Afghanistan, Creighton Law Review, 283-294

KLEFFNER, JANN K., Improving compliance with international humanitarian law through the establishment of an individual complaints procedure, 15 LJIL (1) 237250

KIHL, YOUNG WHAN, Security on the Korean peninsula: continuity and change 33 Security dialogue (1) 59-72

KIVIMDKI, TIMO, War or peace in the South China Sea? NIAS Press, Copenhagen, 213p.

KWAK, TAE-HWAN and JOO, SEUNG$\mathrm{HO}$, The Korean peace process: problems and prospects after the summit, 165 World Affairs (2) 79-90

LIJUN, SHENG, Peace over the Taiwan Strait?, 33 Security Dialogue (1) 93-106 
LIPPMAN, MATTHEW, Aerial attacks on civilians and the humanitarian law of war: technology and terror from World War I to Afghanistan, 33 California Western International Law Journal (1) 1-67

MALEY, WILLIAM, Twelve theses on the impact of humanitarian intervention, 33 Security Dialogue (3) 265-278

MANSFIELD, EDWARD D. and SNYDER, JACK, Democratic transitions, institutional strength, and war, 56 International Organization (2) 297-337

MARSDEN, PETER, The Taliban: war and religion in Afghanistan, Zed Books, London, 162p.

MATHESON, MICHAEL J., United Nations governance of post-conflict societies: East Timor and Kosovo, in Post-conflict Justice, ed. by M. Cherif Bassiouni, 523536

MCCLELLAND, J., Starting from scratch: the military discipline system of the East Timor Defence Force, 7 JCSL(2) 253-273

MCGRATH, RAYMOND, Problems of investigations into war crimes and crimes against humanity during and after ethnic conflicts, in Post-conflict Justice, ed. by M. Cherif Bassiouni, 893-909

MCLAUGHLIN, ROB, Naval force and the conduct of peace support operations, 9 International Peacekeeping (4) 105-118

MIAZAD, OSSAI, Transitional Justice in Post-war Afghanistan, Washington: College of Law, American University,

Military Technical Agreement between the International Security Assistance Force (ISAF) and the Interim Administration of Afghanistan ("Interim Administration"), 41 International Legal Materials (5) 10321037
NADOURY, ASHRAF, Iraq claims summary, 30 IBL (7) 319-321

NOJUMI, NEAMATOLLAH, The rise of the Taliban in Afghanistan: mass mobilization, civil war, and the future of the region, Palgrave, New York, 260p.

NOWAR, MAAN ABU, The Jordanian-Israeli war 1948-1951: a history of the Hashemite Kingdom of Jordan, Reading: Ithaca Press, 515p.

O'CALLAGHAN, ERIN M., Expedited removal and discrimination in the asylum process: the use of humanitarian aid as a political tool, 43 William and Mary Law Review (4) 1747-1775

O'CONNELL, MARY ELLEN, Humanitarian assistance in non-international armed conflict: the fourth wave of rights, duties and remedies, 31 Israeli Yearbook of Human Rights, 183-217

OCRAN, T. MOBIDO, The doctrine of humanitarian intervention in light of robust peacekeeping, 25 Boston College International and Comparative Law Review (1) 1-58

OETTE, LUTZ, A decade of sanctions against Iraq: never again!: the end of unlimited sanctions in the recent practice of the UN Security Council, 13 EJIL (1) 93-103

OH, CECILIA Y., The effect of reunification of North and South Korea on treaty status, 16 Emory International Law Review (1) 311-349

OSMAN, MOHAMED AWAD, The United Nations and peace enforcement: wars, terrorism and democracy, Ashgate, 224p.

PETERSEN, CAROLE J., National security offences and civil liberties in Hong Kong: a critique of the Government's "Consulta- 
tion" on Article 23 of the Basic Law, 32 Hong Kong Law Journal (3) 457-470

POLTAK, CELESTE, Humanitarian intervention: a contemporary interpretation of the Charter of the United Nations, 60 University of Toronto Faculty of Law Review (2) $1-38$

PRICE, MONROE E. and THOMPSON, MARK, Forging peace: intervention, human rights and the management of media space, Edinburgh University Press, 408p.

PRINCE EL HASSAN BIN TALAL of Jordan, Arabism in the twentieth century: war for independence, 58 World Today (1) 6-10

PROVOST, RENI, International human rights and humanitarian law, Cambridge University Press, 418p.

QUINN, BRIAN J.M., Legal reform and its context in Vietnam, 15 Journal of Asian Law (2) 219-291

REITMAN, JONATHAN W., Ten principles to aid the quest for peace in the Middle East, 57 Dispute Resolution Journal (1) 48-55

ROBINSON, J.A., International humanitarian and human-rights law pertaining to child civilians in armed conflict: an overview, 65 Tydskrif vir hedendaagse RomeinsHollandse reg (2) 186-202

ROSCHER, BERNHARD, The "renunciation of war as an instrument of national policy", 4 Journal of the History of International Law (2) 293-309

ROTHSTEIN, ROBERT L., Maoz, Moshe and Shikaki, Khalil, The IsraeliPalestinian peace process: Oslo and the lessons of failure: perspectives, pre- dicaments and prospects, Sussex Academic Press, Brighton, 174p.

SAXON, DAN, Robbery against humanity: the treatment in international humanitarian law of economic crime as a basis for persecution and genocide, 2 Forum on Crime and Society (1) 101-108

SCHEIBER, HARRY N., Taking responsibility: moral and historical perspectives on the Japanese war-reparations issues, 20 Berkeley Journal of International Law (1) 233-249

SCHNEIDER, TODD, David v. Goliath?: the Hong Kong Courts and China's National People's Congress Standing Committee, 20 Berkeley Journal of International Law (3) $575-599$

SIMONE, JOSEPH, Anti-counterfeiting in the PRC: update on criminal, civil and administrative enforcement, 16 CLP (4) 22-28

SMITH, THOMAS W., Moral hazard and humanitarian law: the International Criminal Court and the limits of legalism, 39 International Politics (2) 175-192

SPONECK, H.C. GRAF, Sanctions and humanitarian exemptions: a practitioner's commentary, 13 EJIL (1) 81-87

TABALUJAN, BENNY S., Why Indonesian corporate governance failed: conjectures concerning legal culture, 15 Journal of Asian Law (2) 141-171

TERRIS, ROBERT and INOUE-TERRIS, VERA, A case study of third world jurisprudence: Palestine: conflict resolution and customary law in a neopatrimonial society, 20 Berkeley Journal of International Law (2) 462-495

TRIGGS, GILLIAN, Proposed Timor Sea Arrangements between Australia and the 
East Timor Transitional Administration, 20 Journal of Energy and Natural Resources Law (1) 40-49

USMAN, JEFFREY, The revolution of Iranian Islamism from the revolution through the contemporary reformers, 35 VJTL (5) 1679-1730

VAN DER WOLF, RENI and VAN DER WOFL, WILLEM-JAN (ed.), Laws of war and International Law, Part: Vol. 1 , Wolf Legal Publishers (WLP), Nijmegen, 402p.

VAN DEVEN, NICHOLAS P., Taking one for the team: principle of treaty adherence as a social imperative for preserving globalization and international legal legitimacy as upheld in World War II era Japanese forced labor litigation, 46 Saint Louis University law Journal (4) 1091-1123

\section{TERRITORY AND JURISDICTION}

AL-ENAZY, ASKAR HALWAN, The "International Boundary Treaty" (Treaty of Jeddah) concluded between the Kingdom of Saudi Arabia and the Yemeni Republic on June 12, 2000; 96 AJIL (1) 161-173

CHIU, HUNGDAH, The problem of delimiting the maritime zone between China (Mainland and Taiwan) and Japan In Liber amicorum judge Shigeru Oda ed. by Nisuke Ando, Edward McWhinney, Rudiger Wolfrum 1031-1035

EVANS, MALCOLM D., Case concerning maritime delimitation and territorial questions between Qatar and Bahrain (Qatar v Bahrain), 51 ICLQ (3) 709-718

KAYE, STUART B. and ROTHWELL, DONALD R., Southern Ocean boundaries and maritime claims: another Antarctic challenge for the law of the sea?, 33 OCDIL(3-4) 359-389

KWIATKOWSKA, BARBARA, The Qatar v. Bahrain maritime delimitation and territorial questions case, 33 OCDIL (3-4) 227-262

MENDELSON, MAURICE, The curious case of Qatar v. Bahrain in the International Court of Justice, 72 British Yearbook of International Law, 183-211

MERRILLS, J.G., Sovereignty over Pulau Ligatan and Pulau Sipadan (Indonesia v Malaysia): the Philippines' intervention, 51 ICLQ (3) 718-722

PLANT, GLEN, Maritime delimitation and territorial questions between Qatar and Bahrain, 96 AJIL (1) 198-210

POLAT, NECATI, Boundary issues in Central Asia, Ardsley, NY: Transnational, 282p.

SHEN, JIANMING, China's sovereignty over the South China Sea Islands: a historical perspective, 1 CJIL (1) 94-157

SIEVERS, ERIC W., Transboundary jurisdiction and watercourse law: China, Kazakhstan, and the Irtysh, 37 Texas International Law Journal (1) 1-42

TANAKA, YOSHIFUMI, Reflections on maritime delimination in the QatarBahrain case, 52 ICLQ (1) 53-80

19. UNITED NATIONS AND OTHER INTERNATIONAL/ REGIONAL ORGANISATIONS AND REGIONAL LAWS

ABBOTT, FREDERICK M., North American economic integration: implications for the WTO, the EU and Asia In Regional and 
global regulation of international trade ed. by Francis Snyder, 71-96

A study and evaluation of the UN SecretaryGeneral's Trust Fund to assist states in the settlement of disputes through the International Court of Justice, 1 CJIL (1), 234-279

BLUMENTHAL, DANIEL A., The politics of justice: why Israel signed the International Criminal Court Statute and what the signature means, 30 Georgia Journal of International and Comparative Law (3) 593-615

BROWER, CHARLES N. and BEKKER, PIETER H.F., Understanding "binding" advisory opinions of the International Court of Justice In Liber amicorum judge Shigeru Oda ed. by Nisuke Ando, Edward McWhinney, Rudiger Wolfrum 351-368

CERONE, JOHN, The Special Court for Sierra Leone: establishing a new approach to international criminal justice, 8 ILSA Journal of International \& Comparative Law (2) 379-387

CORINE, JOYCE and JEFFREY, LACSON, Liang (Huefeng) v. People of the Philippines: rethinking the immunities of international organizations, 46 Ateneo law Journal (4) 882-928

DEFOSSE, JONATHAN R., Asian Americans, radical profiling, and national security, 70 The George Washington law Review (1) 181-211

DHAKAL, RAM BABUL, Efforts towards protection of environment under SAARC, 15 NLR (1-2 266-276

FASSBENDER, BARDO, Uncertain steps into a Post-Cold War World: the role and functioning of the UN Security Council after a decade of measures against Iraq, 13 EJIL (1) 273-303

GAJA, GIORGIO, Deliberating on questions of jurisdition in the International Court of Justice In Liber amicorum judge Shigeru Oda ed. by Nisuke Ando, Edward McWhinney, Rudiger Wolfrum 409-417

GOUWLAND-DEBBAS, VERA, The relationship between political and judicial organs of international organisations: the role of the Security Council in the New International Criminal Court In International organizations and international dispute settlement ed. by Laurence Boisson de Chazournes, Cesare P.R. Romano, Ruth Mackenzie, 195-219

HARDING, ANDREW, Global doctrine and local knowledge: law in the South East Asia, 51 ICLQ (1) 35-53

HASSALL, GRAHAM and SAUNDERS, CHERYL, Asia-Pacific constitutional systems, Cambridge University Press, $314 \mathrm{p}$.

HEMMER, CHRISTOPHER and KATZENSTEIN, PETER J., Why is there no NATO in Asia? Collective identity, regionalism, and the origins of multilateralism, 56 International organization (3) 575-607

HULSROJ, PETER, The legal function of the Security Council, 1 CJIL (1) 59-93

HOEKMAN, BERNARD and SCHIFF, MAURICE, Benefiting from regional integration In Development, trade and the WTO ed. by Bernard Hoekman, Aaditya Mattoo and Philip English, 548-558

HUXLEY, TIM, Disintegrating Indonesia?: implications for regional security, Oxford University Press, 349p. 
IWAMOTO, YOSHIYUKI, The protection of human life through provisional measures indicated by the International Court of Justice, 15 LJIL (2) 345-366

JACOBY, TAMI AMANDA and SASLEY, BRENT E. (eds.), Redefining security in the Middle East Manchester University Press, Series, 176p.

MALONE, DAVID M., and HAGMAN, LOTTA (eds.), The North-South divide at the United Nations: fading at last?, 33 Security dialogue (4), 399-414

MO, JOHN, Options to combat maritime piracy in Southeast Asia, 33 OCDIL (3-4) 343-358

ODGAARD, LISELOTTE, Maritime security between China and Southeast Asia: conflict and cooperation in the making of regional order, Ashgate, 296p.

PATEL, BIMAL N. (comp. and ed.), The World Court reference guide: judgments, advisory opinions and orders of the Permanent Court of International Justice and the International Court of Justice (19222000), Kluwer Law International, 957p.

PRAGER, DIETMAR W., Procedural developments at the International Court of Justice, 1 The Law and Practice of International Courts and Tribunals (1) 189-215

RAJAN, RAMKISHEN S. and SEN, RAHUL, Liberalisation of financial services in Southeast Asia under the ASEAN Framework, Agreement on Services (AFAS), 18 Journal of International Banking Law (3) 132-135

SIK, KO SWAN, The attitude of Asian states towards the International Court of Justice revisited, in Liber amicorum Judge Shigeru Oda, ed. by Nisuke Ando, Edward McWhinney and Rudiger Wolfrum, 165176
SUTHIPAND CHIRATHIVAT, Global and regional regulatory changes of foreign direct investment: challenges and opportunities for the ASEAN in the wake of recent turmoil, in Regional and Global Regulation of International Trade, ed. by Francis Snyder, 207-228

SZASZ, PAUL C., The Security Council starts legislating, 96 AJIL (4) 901-905

THIRLWAY, HUGH, Judicial activism and the International Court of Justice, in Liber amicorum Judge Shigeru Oda, ed. by Nisuke Ando, Edward McWhinney and Rudiger Wolfrum, 75-105

THIRLWAY, HUGH, The law and procedure of the International Court of Justice, 72 British Yearbook of International Law, 37-181

UEKI, TOSHIYA, Responsibility of international organizations and the role of the International Court of Justice, in Liber amicorum Judge Shigeru Oda, ed. by Nisuke Ando, Edward McWhinney and Rudiger Wolfrum, 237-249

WALLACE, J. CLIFFORD, Civil pretrial procedures in Asia and the Pacific: a comparative analysis, 34 The George Washington International Law Review (1) $1-16$

WATTS, ARTHUR, The International Court of Justice and the continuing customary International Law of treaties, in Liber amicorum Judge Shigeru Oda, ed. by Nisuke Ando, Edward McWhinney and Rudiger Wolfrum, 251-266

WELLENS, KAREL, Remedies against international organisations, Cambridge University Press, 295p. 
20. WAR, PEACE AND

NEUTRALITY, ARMED

CONFLICT, INTERNATIONAL HUMANITARIAN LAW

WEDGWOOD, RUTH G., Proportionality, cyberwar, and the law of war, in Computer Network Attack and International Law, ed. by Michael N. Schmitt and Brian T. O’Donnell, 219-232

WOLFF, LUTZ-CHRISTIAN, The risk of mixed laws: the example of indirect agency under Chinese contract law, 15 Journal of Asian Law (2) 173-192 